\title{
The big data-business strategy interconnection: a grand challenge for knowledge management. A review and future perspectives
}

\author{
Francesco Ciampi - University of Florence, IT \\ Giacomo Marzi - University of Lincoln, UK (ORCID: 0000-0002-8769-2462) \\ Stefano Demi - University of Florence, IT \\ Monica Faraoni - University of Florence, IT \\ Published on Journal of Knowledge Management
}

FULL TEXT (DOI): $\underline{\text { https://doi.org/10.1108/JKM-02-2020-0156 }}$

\begin{abstract}
Purpose - Designing knowledge management systems capable of transforming big data into information characterised by strategic value is a major challenge faced nowadays by firms in almost all industries. However, in the managerial field, big data is now mainly used to support operational activities, while its strategic potential is still largely unexploited. Based on these considerations, this study proposes an overview of the literature regarding the relationship between big data and business strategy.

Design/methodology/approach - A bibliographic coupling method is applied over a dataset of 128 peerreviewed articles, published from 2013 (first year when articles regarding the big data-business strategy relationship were published) to 2019. Thereafter, a systematic literature review is presented on 116 papers, which were found to be interconnected based on the VOSviewer algorithm.

Findings - This study discovers the existence of four thematic clusters. Three of the clusters relate to the following topics: big data and supply chain strategy; big data, personalisation and co-creation strategies; big data, strategic planning and strategic value creation. The fourth cluster concerns the relationship between big data and knowledge management and represents a 'bridge' between the other three clusters.

Research implications - Based on the bibliometric analysis and the systematic literature review, this study identifies relevant understudied topics and research gaps, which are suggested as future research directions.

Originality/value - This is the first study to systematise and discuss the literature concerning the relationship between big data and firm strategy.
\end{abstract}

Keywords - Big data, Strategy, Bibliometric analysis, Systematisation of literature, Research agenda.

Paper type - Literature review 


\section{Introduction}

Big data (BD) has been regarded as 'the next frontier for innovation, competition, and productivity' (Manyika et al., 2011, p. 1) and the main responsible for the next 'management revolution' (Mcafee and Brynjolfsson, 2012, p. 60). Through the deployment of BD, firms are able to identify opportunities, support decision-making, monitor and improve infra- and inter-company operational processes and investigate changes in consumer tastes and behaviours (Bresciani et al., 2018; Santoro et al., 2019). The success of business strategies based on BD depends on the company's ability to overcome technological barriers and cultural impediments that hinder their implementation (Tabesh et al., 2019). Due to the growing diffusion of BD in the business context, firms increasingly need to redefine their knowledge management systems in order to make them capable of managing the different types of complex data available in a dynamic and transparent way (Intezari and Gressel, 2017). This need derives from a peculiar feature that distinguishes the knowledge extracted from BD; in fact, it is neither explicit nor tacit but 'emergent', as it comes up suddenly and unexpectedly during the observation of the external environment (Patel and Ghoneim, 2011). This leads to define the business intelligence systems of datadriven organisations as socio-technical knowledge systems where BD collected, stored and analysed by machines triggers interactions between data scientists and decision-makers; the latter in turn resort to their past experiences to verify, make sense of and codify the insights extracted, thus contributing to refining the rules and programs on which machine learning routines are based (Lugmayr et al., 2017). This circuit formed by observations and actions taking place continuously and in parallel can be described by the expression 'knowing through making' (Mäkelä, 2007, p. 159), which emphasises how the mutual influence of data analytics activities and human analysts' creative efforts favours the emergence of new valuable knowledge from $\mathrm{BD}$, which bears a potential positive effect on the business in terms of product, service, decision and process optimisation (Kaufmann, 2019).

Designing knowledge management infrastructures capable of transforming BD into strategic information is one of the main challenges faced by firms in recent years. However, in the managerial field, BD is nowadays mainly used to support operational activities, while their strategic potential is still largely unexploited. At the same time no study has so far proposed a systematisation of the literature concerning the relationship between BD and firm strategy. Based on these considerations, this study aims to bridge that gap. We hereby consider 'firm strategy' as a broad concept including organisational decisions of strategic significance related to any company area (from corporate to business and functional levels), strategic purpose (from competitive to growth objectives) and potentiality of overcoming the state of the art (from innovative to disruptive potentialities) for which BD can represent a valuable support (Mazzei and Noble, 2017; Prescott, 2014). Section 2 presents a short review of the fundamental concepts inherent to the management of BD which is functional to highlight the potential benefits deriving from its use for business strategic decision-making. Section 3 describes the methods used in the study. Section 4 discusses the results of the conducted literature review. Section 5 outlines some possible future research directions inspired by this study. Finally, Section 6 presents our conclusions.

\section{Theoretical background}

BD can be defined as data with high informative potential whose size and complexity prevent traditional database software from collecting, storing, managing, processing and analysing it (Manyika et al., 2011). To distinguish BD from traditional datasets, seven dimensions have been identified in the literature, known as the 7 Vs (Mishra et al., 2017). Four of the 7 Vs define the concept of BD: data characterised by considerable size (volume) and heterogeneous nature (variety), rapidly generated and processed (velocity) and subject to unpredictable fluctuations over time (variability). The other three Vs represent desirable attributes of $\mathrm{BD}$, in terms of the insights (value) obtainable, as well as the reliability (veracity) and the graphic representativeness (visualisation) of the information attainable. An organisation's ability to effectively implement BD collection and analysis processes to extract valuable information (i.e. BD 
analytics capabilities; BDAC) is based on the availability of a set of key resources (Mikalef et al., 2017). In this regard, Gupta and George (2016) distinguish three types of resources that are essential for the development of BDAC: tangible resources, intangible resources and human skills. Tangible resources are represented by internal and external data integration techniques, data storage, processing, analysis and visualisation technologies, and investments dedicated to BD initiatives (Gupta and George, 2016). Intangible resources include a corporate culture oriented towards data-driven and evidence-based decision-making at any level of the organisation (Ross et al., 2013) and the intensity of organisational learning, which represents the extent to which the firm acquires, shares, interprets, stocks and applies knowledge extracted from BD (Pérez López et al., 2004). Finally, human skills indicate the technical, managerial and relational skills held by specialist personnel (e.g. data analysts and data scientists) and other employees, which are necessary to effectively implement BD analytics (BDA; Fosso Wamba et al., 2017). BDA are tools that can help organisations 'in the discovery of hidden knowledge and generation of new knowledge' originating from multiple sources (Khan and Vorley, 2017, p. 18). Developing adequate BDAC allows firms to effectively exploit the insights extracted from large datasets, by making them available for business decision-making through advanced knowledge management (KM) systems. Today, BD is mainly used to support company activities at an operational level, such as procurement, production, warehouse management and distribution, in order to increase the rationality, efficiency and speed of routine and recurring decisions (Power, 2015). However, a qualitative leap, aimed at aligning BDAC with the needs of strategic activities, would allow companies to better exploit their information resources, increase the existing synergies between business functions, seize new market opportunities and obtain better performances (Akter et al., 2016). The firms that are fully aware of the fundamental support that can be provided by BDA to strategic decisions are better prepared to successfully face the challenges of today's digital revolution (LaValle et al., 2011; Power, 2015). Specifically, the ability to use descriptive, predictive and prescriptive BDA-enabled techniques, which combine quantitative data with soft elements such as knowledge and managerial intuition, allows to transform the insights emerging from BD into highly valuable and inimitable resources, which can effectively support the processes of strategic orientation, environment observation, formulation and implementation of the chosen strategy (Kunc and O'Brien, 2019).

Based on these premises, the present paper performs a bibliometric analysis, coupled with a systematic literature review, with the aim of offering an overview of the evolution of the literature regarding the BD-business strategy relationship published over the last seven years. Based on the results of the systematic literature review, this study also identifies relevant understudied topics and research gaps, which are suggested as future research directions.

\section{Methodology}

In order to provide a reliable and sufficiently in-depth review of the emerging literature on the relationship between BD and business strategy, this study employs a mixed method. After conducting a bibliometric analysis based on the visualisation of similarities (VOS; Van Eck and Waltman, 2010), we also present a systematic literature review (Tranfield et al., 2003). This methodology has proved useful in many disciplinary contexts, as it identifies the underlying research strands of a given field of study by synthesising and representing high volumes of bibliographic data. The analysis was developed through five stages. The first phase, which took place in January 2020, consisted in selecting the research query. In order to obtain a search criterion able to return an exhaustive list of contributions in the literature that investigate the relationship between $\mathrm{BD}$ and strategy, several iterations were carried out. The following query: " "TITLE-ABS-KEY("big data" AND "strateg*”)" was performed. The "TITLE-ABS-KEY" operator limits the research for the chosen terms to the title, the abstract and the keywords of the relevant papers. 
This query was performed on the Scopus database, which represents the most comprehensive data source to retrieve high-quality and peer-reviewed publications for emerging fields of study (Falagas et al., 2008). The search was limited to:

1. articles, articles in press and reviews that have undergone a double-blind peer-review process (Grégoire et al., 2011);

2. documents published on or before December 31, 2019; and

3. specific disciplinary areas that might involve BD application in business sciences, i.e. Business, Management and Accounting, Social Sciences, Decision Sciences and Economics, Econometrics and Finance.

The retrieved data was cross-checked by applying the same research string on the Web of Science and EBSCO Business Premier databases. This analysis did not identify any missing data, thus confirming the validity of using both our query string and the Scopus database.

Initial dataset: 988

$\begin{array}{ll}\text { Title, Abstract, } & \text { - } 214 \text { papers did not focus on business strategy } \\ \text { Keywords } & \text { - } 62 \text { papers did not focus on big data } \\ & \text { - } 34 \text { papers focused neither on business strategy nor on big data } \\ & \text { - } 463 \text { papers did not link business strategy and big data }\end{array}$

Full texts

- 18 papers did not focus on business strategy

- 5 papers did not focus on big data

- 64 papers did not link business strategy and big data

Final dataset: 128

Figure 1: Protocol for selecting papers

In the second phase, three out of the four authors performed an independent screening of the 988 papers included in the initial dataset. This screening led to remove a large number of papers that did not relate to the theme object of this study, as summarised in Figure 1. Some of the excluded papers did not focus on BD nor business strategy, while others did not analyse any connection between the two themes. In line with the best methodological practices (Tranfield et al., 2003), three out of the four authors analysed the 988 papers independently. For the screening phase, Krippendorf's Alpha coefficient (K) served as a statistical measure of the agreement achieved. The resulted K was higher than 0.80 . Such value indicates robust convergence and strong inter-reliability of the performed selection process. After adopting such selective criteria, the final dataset was reduced to 128 papers.

In the third research phase, the study performed a bibliometric analysis on the final dataset. Specifically, a series of bibliometric activity indicators, concerning the distribution of papers per year, author, journal and country, were first calculated (Todeschini and Baccini, 2016; see Section 4.1). Subsequently, we moved to the core of the bibliometric investigation by using VOSviewer 1.6.10. The software was used for the similarity analysis and aggregating papers through bibliographic coupling (Van Eck and Waltman, 
2010). Bibliographic coupling occurs when two contributions both refer to a third contribution within their bibliographies. This method is useful for mapping the research strands relating to a specific developing literature and for identifying emerging future trends (Boyack and Klavans, 2010). The algorithm considers the number of shared references between documents to group them into different clusters (Van Eck and Waltman, 2010). 116 out of the total 128 papers resulted interconnected with common references, giving form to a four-cluster structure (see Section 4.2). If papers belong to the same cluster, they are strongly linked together and may represent a univocal stream of research or approach (Van Eck and Waltman, 2010).

In the fourth phase, always in line with the best methodological practices (Tranfield et al., 2003), three out of the four authors independently scored these 116 papers according to their relevance for the main topics of each cluster. This step was necessary to focus the analysis on the most relevant papers and make the results of our study as pertinent and significant as possible (Tranfield et al., 2003). It was performed by the authors based on their experience and expertise in the field of BD and strategy. Krippendorf's Alpha coefficient $(\mathrm{K})$ was applied as a statistical measure of the agreement achieved. The resulted $\mathrm{K}$ was higher than 0.80 , showing a robust convergence and a strong inter-reliability of the process. Through this final step, a restricted dataset, composed of 54 papers (around $42 \%$ of the total dataset) was selected. In the fifth and final phase, a systematic literature review was performed (Tranfield et al., 2003).

\section{Results}

\subsection{Results of the bibliometric analysis}

In this section, we analyse a series of bibliometric activity indicators (Table 1).

The distribution of papers by year of publication shows how the field of study is subjected to a progressively increasing academic interest, with 2018 being the most productive year.

\begin{tabular}{|c|c|c|c|}
\hline \multicolumn{4}{|c|}{ Number of papers per year } \\
\hline 2013 & 4 & 2014 & 5 \\
\hline 2015 & 5 & 2016 & 16 \\
\hline 2017 & 26 & 2018 & 43 \\
\hline 2019 & 29 & & \\
\hline \multicolumn{4}{|c|}{ Number of papers per author (only authors with at least two papers published) } \\
\hline Akter S. & 4 & Buganza T. & 4 \\
\hline Fosso Wamba S & 4 & Trabucchi D. & 4 \\
\hline Gražauskas V. & 3 & Gunasekaran A. & 3 \\
\hline Li Y. & 3 & Navickas V. & 3 \\
\hline Tan K.H & 3 & Bouwman H. & 2 \\
\hline Buhalis D. & 2 & Canhoto A. & 2 \\
\hline Côrte-Real N. & 2 & De Bourmont M. & 2 \\
\hline De Reuver M. & 2 & Del Vecchio P. & 2 \\
\hline Dibb S & 2 & Dubey R. & 2 \\
\hline El-Kassar A.-N. & 2 & Nikou S. & 2 \\
\hline Oliveira $\mathrm{T}$. & 2 & Pellizzoni E. & 2 \\
\hline Quinn L. & 2 & Ruivo P. & 2 \\
\hline Simkin L. & 2 & Singh S.K. & 2 \\
\hline Wang $\mathrm{H}$. & 2 & Wang X. & 2 \\
\hline Wu Y. & 2 & Zhan Y. & 2 \\
\hline Zhang Y. & 2 & Zhou Y. & 2 \\
\hline \multicolumn{4}{|c|}{ Number of papers per journal (only journals with at least two papers published) } \\
\hline Information and Management & 6 & $\begin{array}{l}\text { International Journal of } \\
\text { Production Economics }\end{array}$ & 5 \\
\hline Journal of Business Research & 4 & Journal of Cleaner Production & 4 \\
\hline Journal of Knowledge Management & 4 & $\begin{array}{l}\text { Business Process Management } \\
\text { Journal }\end{array}$ & 3 \\
\hline
\end{tabular}




\begin{tabular}{|c|c|c|c|}
\hline $\begin{array}{l}\text { Creativity and Innovation } \\
\text { Management }\end{array}$ & 3 & $\begin{array}{l}\text { Industrial Marketing } \\
\text { Management }\end{array}$ & 3 \\
\hline Management Decision & 3 & $\begin{array}{l}\text { Technological Forecasting and } \\
\text { Social Change }\end{array}$ & 3 \\
\hline Amfiteatru Economic & 2 & Business Horizons & 2 \\
\hline $\begin{array}{l}\text { Electronic Commerce Research and } \\
\text { Applications }\end{array}$ & 2 & $\begin{array}{l}\text { International Journal of } \\
\text { Hospitality Management }\end{array}$ & 2 \\
\hline $\begin{array}{l}\text { International Journal of Information } \\
\text { Management }\end{array}$ & 2 & $\begin{array}{l}\text { International Journal of } \\
\text { Logistics Management }\end{array}$ & 2 \\
\hline $\begin{array}{l}\text { International Journal of Production } \\
\text { Research }\end{array}$ & 2 & $\begin{array}{l}\text { Journal of Management } \\
\text { Information Systems }\end{array}$ & 2 \\
\hline Journal of Services Marketing & 2 & Journal of Strategic Marketing & 2 \\
\hline Meditari Accountancy Research & 2 & $\begin{array}{l}\text { Research Technology } \\
\text { Management }\end{array}$ & 2 \\
\hline Strategic Direction & 2 & & \\
\hline \multicolumn{4}{|c|}{ Number of papers per country (only countries with at least two papers published) } \\
\hline United States & 36 & United Kingdom & 25 \\
\hline China & 16 & Italy & 17 \\
\hline Australia & 13 & France & 8 \\
\hline Finland & 5 & Denmark & 4 \\
\hline Ireland & 4 & Netherlands & 4 \\
\hline Romania & 4 & Taiwan & 4 \\
\hline United Arab Emirates & 4 & Canada & 3 \\
\hline Germany & 3 & India & 3 \\
\hline Lithuania & 3 & New Zealand & 3 \\
\hline Belgium & 2 & Hong Kong & 2 \\
\hline Lebanon & 2 & Malaysia & 2 \\
\hline Norway & 2 & Portugal & 2 \\
\hline Spain & 2 & South Korea & 2 \\
\hline
\end{tabular}

Table 1: Bibliometric activity indicators

There are no particularly prolific researchers (less than $10 \%$ of the selected authors produced more than one article), probably due to the still embryonic state of the thematic area object of our analysis. The data exposed also shows a high degree of variety in the disciplinary areas of the journals where the contributions were published in accordance with the semantic breadth of the reading key (strategy) with which the topic of BD is investigated. Finally, the distribution by country shows that Europe is overall the most prolific continent to date (approximately $47 \%$ of the contributions).

\subsection{Results of the VOS clustering process and the systematic literature review}

The cluster structure (Figure 2) indicates that papers are well-connected and consider fairly similar streams of literature. The VOS analysis allowed us to identify a four-cluster structure, with two clusters (i.e. the red and the blue ones) being the best defined. The green cluster can be considered, by position and content, as a 'bridge' connecting the other three clusters. In fact, it collects studies that highlight how BDA can support knowledge management strategy, allowing information to be extracted from BD and converted into valuable knowledge, sharable inside and outside the organisation.

The yellow cluster assembles studies that examine the impact of BD on strategic supply chain (SC) management. The red cluster aggregates contributions that explore the opportunities offered by BD for the personalisation of marketing and innovation strategies. The blue cluster groups studies that focus on BD-driven value creation strategies. 


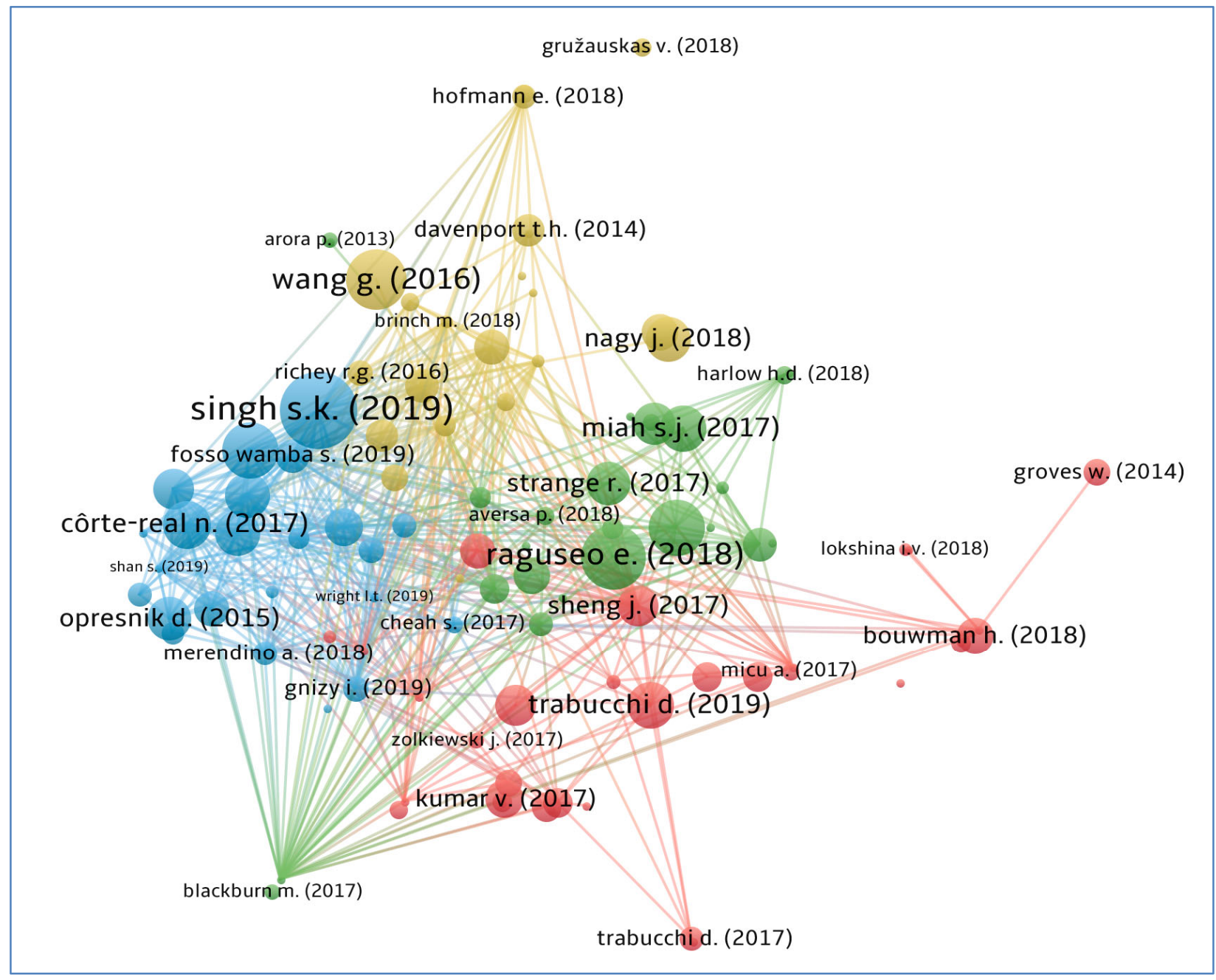

Figure 2: VOS coupling structure

Table 2 anticipates the main topics covered in each cluster, with indication of the related exemplary references.

In the following paragraphs, the results of the systematic literature review conducted on each cluster are presented.

\begin{tabular}{|l|l|}
\hline \multicolumn{1}{|c|}{ MAIN TOPICS } & \multicolumn{1}{|c|}{ EXEMPLARY REFERENCES } \\
\hline \multicolumn{2}{|c|}{ Yellow cluster: Big data and supply chain strategy } \\
\hline Big data to support supply chain strategy & $\begin{array}{l}\text { Brinch (2018); Handfield } \text { et al. (2019); Nguyen Dang } \\
\text { Tuan } \text { et al. (2019); Wang } \text { et al. (2016) }\end{array}$ \\
\hline $\begin{array}{l}\text { Big data to facilitate supplier and strategic partners } \\
\text { collaboration }\end{array}$ & $\begin{array}{l}\text { Nagy } \text { et al. (2018); Navickas and Gružauskas (2016); } \\
\text { G. Wang et al. (2016) }\end{array}$ \\
\hline Big data and supply chain agility & $\begin{array}{l}\text { Fosso Wamba, Dubey, } \text { et al. (2019); Li and Wang } \\
\text { (2017); Richey } \text { et al. (2016); Roßmann } \text { et al. (2018); } \\
\text { Wang } \text { et al. (2016) }\end{array}$ \\
\hline Big data and supply chain sustainability & $\begin{array}{l}\text { El-Kassar and Singh (2019); Gružauskas } \text { et al. } \\
\text { (2018); G. Wang } \text { et al. (2016); Zhang } \text { et al. (2018) }\end{array}$ \\
\hline \multicolumn{2}{|c|}{ Red cluster: Big data, personalisation and co-creation strategies } \\
\hline $\begin{array}{l}\text { Big data and segmentation, targeting and positioning } \\
\text { strategies }\end{array}$ & $\begin{array}{l}\text { Ahani } \text { et al. (2019); Kumar } \text { et al. (2017); Quinn } \text { et al. } \\
\text { (2016); Taylor-West } \text { et al. (2018) }\end{array}$ \\
\hline
\end{tabular}




\begin{tabular}{|c|c|}
\hline $\begin{array}{l}\text { Big data and Open Innovation: 'user-centred' } \\
\text { strategies }\end{array}$ & $\begin{array}{l}\text { Bendle and Wang (2016); Qi et al. (2016); Trabucchi } \\
\text { et al. (2018) }\end{array}$ \\
\hline $\begin{array}{l}\text { Big data and Open Innovation: 'user-driven' } \\
\text { strategies }\end{array}$ & $\begin{array}{l}\text { Buhalis and Sinarta (2019); Kunz et al. (2017); } \\
\text { Trabucchi et al. (2018); Xie et al. (2016) }\end{array}$ \\
\hline Innovative strategies for the exploitation of big data & $\begin{array}{l}\text { Sorescu (2017); Trabucchi and Buganza (2019a, } \\
\text { 2019b); Trabucchi et al. (2017) }\end{array}$ \\
\hline \multicolumn{2}{|c|}{ Blue cluster: Big data, strategic planning and strategic value creation pathways } \\
\hline Big data as a driver of strategic planning & $\begin{array}{l}\text { Constantiou and Kallinikos (2015); Gnizy (2019); } \\
\text { Mazzei and Noble (2017); O'Connor and Kelly } \\
\text { (2017) }\end{array}$ \\
\hline Value creation pathways enabled by big data & $\begin{array}{l}\text { Elia et al. (2019); Grover et al. (2018); Y. Wang et } \\
\text { al. (2018) }\end{array}$ \\
\hline $\begin{array}{l}\text { Big data and strategic value creation paths from a } \\
\text { Resource-Based View perspective }\end{array}$ & $\begin{array}{l}\text { Cheah and Wang (2017); Grover et al. (2018); } \\
\text { Roden et al. (2017) }\end{array}$ \\
\hline $\begin{array}{l}\text { Big data and strategic value creation paths from a } \\
\text { Dynamic Capabilities perspective }\end{array}$ & $\begin{array}{l}\text { Côrte-Real et al. (2017, 2019); Grover et al. (2018); } \\
\text { Prescott (2014) }\end{array}$ \\
\hline $\begin{array}{l}\text { Big data and strategic value creation paths from a } \\
\text { strategic alignment theory perspective }\end{array}$ & Akter et al. (2016); Grover et al. (2018) \\
\hline \multicolumn{2}{|c|}{ Green cluster: Big data and knowledge management } \\
\hline $\begin{array}{l}\text { Influence of big data on knowledge management } \\
\text { strategies }\end{array}$ & $\begin{array}{l}\text { Harlow (2018); Intezari and Gressel (2017); } \\
\text { Landaeta Olivo et al. (2016); Tian (2017) }\end{array}$ \\
\hline Big data and decision support systems & $\begin{array}{l}\text { Aversa et al. (2018); Festa } \text { et al. (2018); Osuszek et } \\
\text { al. (2016) }\end{array}$ \\
\hline $\begin{array}{l}\text { Big data for the development of collaborative } \\
\text { knowledge networks }\end{array}$ & $\begin{array}{l}\text { Buhalis and Leung (2018); Del Vecchio, Di Minin, et } \\
\text { al., (2018); Romanelli (2018); Troisi et al. (2018) }\end{array}$ \\
\hline Big data and knowledge sharing using Web 2.0 & $\begin{array}{l}\text { Arora and Predmore (2013); Del Vecchio, Mele, et } \\
\text { al. (2018); Richard (2017) }\end{array}$ \\
\hline
\end{tabular}

Table 2: Main topics discussed in each cluster and exemplary references

\subsubsection{Yellow cluster: Big data and supply chain strategy}

This cluster aggregates studies that highlight how BDA, managed through shared platforms, allow the development of effective SC management strategies and improve the collaboration between SC actors as well as the SC agility and sustainability. Brinch (2018) shows how the use of a properly articulated ecosystem of BD related to infra- and inter-organisational processes can provide new opportunities regarding the optimisation, innovation and reorganisation of SC activities. Specifically, at a strategic level, BDA can be used to support strategic sourcing, SC network configuration and new product design and development activities (Wang et al., 2016).

With reference to strategic sourcing activities, BDA enable the construction of cost prediction and risk assessment models. These models prove useful to analyse the spending profiles of current and potential suppliers, select new suppliers based on the best value proposals and monitor the activity of existing suppliers and supply market dynamics to avoid risks of interruptions within the production cycle (Handfield et al., 2019; Wang et al., 2016). With regard to the physical configuration of the SC, BDA can support decisions regarding the number, position and size of production plants and distribution centres, mainly through optimisation and what-if analysis techniques (Nguyen Dang Tuan et al., 2019). Finally, BDA speed up new product development processes and ensure their adequacy with respect to the quality standards and cost targets (Wang et al., 2016).

To assess the extent to which the company uses BDA to make strategic decisions, Wang et al. (2016) propose a maturity framework that considers three strategic objectives relating to the SC: collaboration, agility and sustainability.

Firstly, BD facilitates the collaboration with business partners, which guarantees knowledge sharing and better decision-making within the SC. Nagy et al. (2018) argue that Industry 4.0 technologies help develop a 'digital ecosystem' based on collaborations with suppliers, customers and other strategic 
partners, where relevant data and information are shared and available at any time within the cloud, thus allowing to develop a really interconnected and 'customer-centric' SC. An example of this ecosystem is provided by Navickas and Gružauskas (2016), who focus on small and medium-sized enterprises operating in the food industry market niches. The authors suggest that these companies form collaborative clusters to exploit the SC digitisation so as to optimise logistics costs and shared profits and increase their competitiveness. The development of an effective shared platform between members of the same SC can be achieved through appropriate KM systems allowing business partners to have access to the same valuable and reliable information usable for both individual and joint decision-making. Secondly, the use of BDA increases SC agility, which can be defined as the ability to monitor and respond to external changes in real time. In this regard, Fosso Wamba et al. (2019) demonstrate the positive impact of BDA-enabled dynamic capability on the degree of agility, adaptability and, consequently, ambidexterity of the SC. Richey et al. (2016) argue that by using BDA, a firm can connect technology, market, consumer needs and innovation, reconfigure and adapt its resources and capabilities and, therefore, deal with environmental changes with greater readiness. In the face of an increasing complexity characterising the SC, BDA usage allows to moderate this uncertainty by guaranteeing a greater transparency of the collected information and a better quality and accuracy of the forecasting activities (Roßmann et al., 2018). A particular application of BD for forecasting purposes is offered by Li and Wang (2017). Focusing on the fresh food chain and on BD collected through a network of sensors and RFID technologies, the authors propose a dynamic pricing strategy able to predict the residual shelf life of products at any stage of the SC.

Finally, BDA can be used for the development of an environmentally sustainable SC strategy. El-Kassar and Singh (2019) prove that BD-based predictive analysis tools indirectly influence the competitive advantage by facilitating green innovation practices. Gružauskas et al. (2018) introduce a logistics network model for the food SC, based on Industry 4.0 technologies, which incorporates the optimal distribution strategy capable of minimising the trade-off between sustainability (reduction of $\mathrm{CO}_{2}$ emissions) and competitiveness (reduction of transport costs). Zhang et al. (2018) develop an analytical framework that combines BDA with traditional methods for energy consumption analysis to examine and solve energy waste problems and, therefore, increase the competitiveness of energy-intensive manufacturing companies.

\subsubsection{Red cluster: Big data, personalisation and co-creation strategies}

The red cluster includes contributions that underline how BD provides information and knowledge regarding the needs, interests and behaviours of individual customers. They, therefore, encourage the use of BDA to personalise marketing strategies, customise and co-create innovation and new product development strategies, as well as develop effective business model innovation strategies. Quinn et al. (2016) claim that data manipulation, usually attributed to chief data officers or external digital agencies, and the formulation of marketing strategies, for which the marketing department is responsible, should be performed in a complementary and collaborative way. In so doing, the digital vision and marketing approaches can mutually reinforce each other and help manage the growing complexity of the market. For example, by using BDA the firm is able to effectively analyse the heterogeneity of preferences within different market segments and thus better personalise its value proposition ('one-to-one' approach).

Several contributions refer to the opportunity of using customer-generated BD to determine new segmentation criteria, based on variables such as price sensitivity and customer engagement (Kumar et al., 2017), customer opinions regarding the relevance of certain product or service attributes (Ahani et al., 2019) and the degree of knowledge and familiarity towards the product or service (Taylor-West et al., 2018). The development of a clear segmentation strategy represents an essential precondition to identifying and satisfying consumer needs. This activity is positioned upstream of the innovation cycle, with respect to which $\mathrm{BD}$ can play a facilitating role in the adoption of open innovation (OI) strategies 
(Trabucchi et al., 2018) by triggering the creation of knowledge flows that cross company borders (Chesbrough and Bogers, 2014). As a matter of fact, the company has the opportunity to use the knowledge extracted from multi-source data, especially User-Generated Big Data (UGBD), to optimise and speed up the internal innovation process (inbound OI) and the external diffusion and exploitation process (outbound OI). There are two literature streams that interpret the different roles played by users in supporting the development of business innovations: the user-centred innovation (UCI) approach and the user-driven innovation (UDI) approach (Trabucchi et al., 2018).

The UCI approach implies that the company exploits the insights deriving from the mere observation of the behaviours, opinions and needs expressed by customers during the use of products and services for new product development activities (Trabucchi et al., 2018). In this regard, BDA represent a more effective alternative tool, as compared to traditional methods such as interviews, focus groups and applied ethnography, because they allow the company to collect several information spontaneously generated by users (Bendle and Wang, 2016; Qi et al., 2016), benefiting from a low cost and a high replicability.

Using the UDI approach the company develops and prototypes new products in collaboration with individual customers (Trabucchi et al., 2018). UGBD can foster the effectiveness of the UDI approach, as it can provide valuable information to sustain the ideas generated by the lead users, enrich user toolkits with context-related information and even support crowdsourcing platforms. The customer engagement model proposed by Kunz et al. (2017) helps to understand how UGBD can contribute to value cocreation. By using UGBD for the UCI approach, firms can exploit the online content freely generated by customers without their awareness. On the contrary, by using UGDB for the UDI approach, companies can develop a 'real collaboration' since the user offers his ideas directly and consciously to the company, favouring the establishment of value co-creation processes. Such collaboration usually takes place within dedicated online communities, where customer-generated BD of different nature (i.e. transactional, communication, participative, transboundary) and the digital platforms specifically made available by the company for its collection are transformed into cooperative assets capable of bringing benefits in a bilateral and stable manner (Xie et al., 2016). For instance, Buhalis and Sinarta (2019) highlight how the information exchange between the firm and the customers increases the opportunity to dynamically cocreate services and experiences that are perceived as current and attractive by the consumer ('nowness'). Trabucchi et al. (2017) identify three main strategies for exploiting BD in the context of the so-called multi-sided platforms (i.e. markets in which the providers of goods or services act as intermediaries in the interaction between two or more groups of users). The first, 'enhanced advertising', is a strategic option by which a company uses consumer data to propose highly contextualised advertising messages tailored on user preferences. The second, 'e-ethnography', is a strategy by which companies consider data relating to consumer habits, needs and relations as 'by-products' functional to the improvement of its core products and services and even as a final innovative output capable of automatically strengthening the corporate value proposition (Trabucchi and Buganza, 2019a). Lastly, in the third strategy, 'data trading', user data is directly sold to a third party, thus becoming a revenue-generating asset itself. The variety of strategic options enabled by UGBD makes their use capable of not only increasing the effectiveness and efficiency of product and service development and improvement but also triggering business model innovations, thanks to their significant impact on value creation, value appropriation and value delivery mechanisms (Sorescu, 2017; Trabucchi and Buganza, 2019b). The disclosure of the several opportunities that can be achieved through BD exploitation leads to consider the knowledge extracted from it as an important enabler (and not only a mere supporter) of firms' value creation processes.

\subsubsection{Blue cluster: Big data, strategic planning and strategic value creation pathways}


This cluster groups the contributions that analyse the impact of BD on strategic planning processes and outline the strategic paths through which firms can convert their BDAC into value.

With reference to the strategy-making context, Constantiou and Kallinikos (2015) highlight how the randomness, heterogeneity, updatability, lack of structure and the trans-semiotic and agnostic nature that distinguish BD significantly impact the assumptions on which the strategic formulation process is based. On the one hand, these characteristics lead to questioning the traditional top-down and deductive approaches of data collection and use, based on cognitive schemes outlined a priori in favour of bottomup and inductive procedures extracting information from BD in a de-contextualised manner, so as to satisfy a variety of strategic purposes identified on the spot. On the other hand, they diminish the relevance of long-term forecasting approaches by facilitating a greater focus on the present ('nowcasting').

According to Mazzei and Noble (2017), in the strategic planning context, BD can be exploited to solve the problems related to the traditional activities of the value chain more effectively ('data as a tool'), to create industries based on the sale of data and software for data management ('data as an industry') or to inform company strategies through the countless market opportunities identifiable through BD analysis ('data as a strategy'). By explicitly adopting the 'data as a strategy' perspective, Gnizy (2019) demonstrates how BDA can influence some strategic orientations pursued by international companies and, consequently, their performance. Specifically, they can improve the engagement of existing customers and the acquisition of new ones, thanks to the greater understanding of their needs and desires (market orientation); they can also continuously provide new transparent and reliable knowledge to support the company's propensity to take risky and innovative decisions (entrepreneurial orientation); they can finally strengthen a company learning efforts, by allowing to use the knowledge extracted from $\mathrm{BD}$ in a more effective way (learning orientation). At the same time, using an opposite perspective, O'Connor and Kelly (2017) find that the strategic orientation acts as an enabler of the organisation's readiness to effectively exploit the insights deriving from large datasets.

Several contributions belonging to this cluster focus on the strategic value creation paths that can be enabled by using BDA within the firm. Wang et al. (2018) develop a BDA-enabled transformation model that illustrates how the presence in the company of widespread IT capabilities and functionalities enables different combinations of organisational change practices directed to improve the company's ability to create value. Elia et al. (2019) propose a multidimensional framework that identifies different types of value directions (i.e. informational, transactional, transformational, strategic and infrastructural) that can be pursued through the adoption of the BD paradigm.

In developing his own BD-based conceptual model of value creation, Grover et al. (2018) consider several theories: Resource-Based View (RBV), Dynamic Capabilities View (DCV), IT-Strategy Alignment Theory and Absorptive Capacity Theory. Following the logic of the RBV, the attributes of heterogeneity and immobility (i.e. the difficult availability for other companies) that characterise BD resources are by themselves functional to the value generation. In this regard, Roden et al. (2017) and Cheah and Wang (2017) consider BD as a precious and inimitable form of information resource that provides the necessary knowledge to seize the opportunities for incremental and radical innovation of operations models and business models respectively. According to DCV, the value of BDA increases when opportunities can be identified and exploited through the flexible reconfiguration of resources and value creation mechanisms, especially in the presence of changing environmental conditions. In this connection, Prescott (2014) believes that the competitive advantage achieved thanks to the ownership of valuable, rare, inimitable and non-replaceable resources is difficult to maintain over time if the company fails to avert their transformation into core rigidities (i.e. DCV). Specifically, as proven in the studies of Côrte-Real et al. (2017, 2019), BDAC, being functional for the collection of data, information and knowledge in real time, represent fundamental dynamic capabilities for the optimisation of company resources and operating routines. They, in turn, strengthen other dynamic capabilities (e.g. organisational 
agility), with positive relapses on the company competitiveness and ability to create value. Furthermore, the IT-Strategy Alignment Theory suggests that the efficiency and effectiveness achievable by using BDA can be strengthened by maintaining a certain consistency between strategy, resources, capabilities, processes and corporate governance practices (Akter et al., 2016). Finally, Grover et al. (2018) consider the perspective of the Absorptive Capacity Theory (i.e. a firm's capability to recognise, assimilate and exploit the value of new external knowledge) and outline how BD resources and capabilities allow firms to identify valuable external knowledge emerging from data that can be transformed into internal knowledge useful for innovating and adopting effective competitive strategies.

\subsubsection{Green cluster: Big data and knowledge management}

The green cluster can be considered, by position and content, a 'bridge' connecting the three clusters previously analysed. It collects studies that highlight how BDA support KM strategies. Information extracted from BD can be converted into valuable knowledge to be exploited and shared inside and outside the organisation. Companies increasingly feel the need to redefine their KM systems in order to make them capable of managing and integrating the multi-faceted and complex data available in a dynamic and transparent way (Intezari and Gressel, 2017). Furthermore, BD is expected to revolutionise the entire field of KM by questioning traditional theoretical perspectives (e.g. the 'data-informationknowledge continuum') and therefore impacting on the very nature of decision-making processes (which is increasingly becoming a function of predictive modelling rather than a priori assumptions; Tian, 2017).

Landaeta Olivo et al., 2016 propose a framework for the implementation of organisational learning models based on BD management principles. They highlight how incorporating BD in KM systems allows improving the quality and mitigating the risks of decision-making. In the same direction, the Big Data/Analytics-Knowledge Management model proposed by Pauleen and Wang (2017) explains how the use of BDA fosters and is in turn fuelled by the existing organisational knowledge. In particular, after identifying the reasons why it is necessary to collect and analyse data, on one hand, business analysts use the available 'contextual knowledge' (i.e. the human knowledge and experience accumulated in the organisation) in order to select the most appropriate BDA to extract useful insights. On the other hand, they use these insights to solve pre-existing problems or formulate new strategies aimed to pursue sustainable competitive advantage (Harlow, 2018). Festa et al. (2018) advise firms characterised by 'structural' ambidexterity (i.e. which use dual organizational structures and strategies to differentiate efforts towards exploitation and exploration, as in the case of big pharma, which is naturally oriented to innovate rapidly and efficiently while still controlling risks and current sales), to adopt knowledge process standardisation as the main coordination mechanism for managing 'big knowledge' in order to simultaneously strengthen the exploitation of current activities and the exploration of future opportunities. Osuszek et al. (2016) overcome the perspective of business process management, which considers the single processes in a static and defined way, to adopt the adaptive case management (ACM) perspective, oriented to the timely and dynamic modification of business processes through a continuous experimentation of shared knowledge at an organisational level. The authors state that the dynamic ACM systems incorporating $\mathrm{BD}$, being able to provide accurate and updated information regarding single business processes, facilitate the automation and optimisation of decision-making and the adoption of evidence-based approaches that are less dependent on managerial intuition. Nevertheless, the benefits associated with Decision Support Systems (DSS) powered by BD are not entirely foolproof. In this regard, Aversa et al. (2018) believe that the characteristics of the social, physical and technical environment, the distribution of decision-making activities among individuals and corporate artefacts as well as the performativity of DSS models may also negatively influence the assumptions and methods of data-driven decision-making in organisations. 
The possibility to effectively incorporate BD into corporate KM systems is connected to the company ability to develop reliable external knowledge networks, which in turn represent fundamental strategic means for the development of effective OI and co-creation strategies (Del Vecchio, Di Minin, et al., 2018). For example, knowledge-based organisations (e.g. museums) benefit from data-driven strategies if they manage to turn their physical and virtual environments into collaborative cultural ecosystems, in which users and other stakeholders participate actively to the creation and sharing of cultural contents through interactive learning experiences (Romanelli, 2018), while manufacturing firms can support new product development processes by introducing engagement online platforms where consumers spontaneously express their opinions and suggestions regarding purchased products (Troisi et al., 2018). Finally, some studies highlight how the presence of BD-enabled KM systems favours, in addition to collaborative innovation, greater inter-connection and inter-operability between partner companies of the same SC, thus allowing an effective joint operational and strategic planning (Buhalis and Leung, 2018). Lastly, still in the context of collaboration and knowledge sharing inside and outside the organisation, there are several contributions belonging to this cluster that focus on the opportunities offered by Web 2.0 tools. For instance, Arora and Predmore (2013) claim that social networks enable the creation of an open and transparent corporate environment, where anyone can intervene to propose innovative ideas (concerning products and business processes). Such ideas are then selected and implemented by the organisation (i.e. 'crowdsourcing'). Del Vecchio, Mele, et al. (2018) show how the exploitation of social $\mathrm{BD}$ allows tourism companies to configure data-driven business models, based on the exchange of local experiences and inspired by the principles of collaboration, networking and crowdsourcing. Finally, Richard (2017) suggests that hotel chains may want to take advantage of UGBD available on social networks to create more customised services, tailored on customers' needs and interests ('microsegmentation').

\section{Future research directions}

The bibliometric analysis and literature review presented in the previous sections pave the way to several future research avenues (Tranfield et al., 2003) within each of the four thematic clusters (Table 3).

\begin{tabular}{|c|c|}
\hline FUTURE RESEARCH AVENUES & EXEMPLARY REFERENCES \\
\hline \multicolumn{2}{|c|}{ Yellow cluster: Big data and supply chain strategy } \\
\hline $\begin{array}{l}\text { Deepen the role of big data in modifying information } \\
\text { systems, processes, controls and decision-making practices } \\
\text { characterising the supply chain }\end{array}$ & Brinch (2018); Tan et al. (2015) \\
\hline $\begin{array}{l}\text { Examine how the willingness and the different approaches } \\
\text { to collaborate influence big data usage in the supply chain }\end{array}$ & $\begin{array}{l}\text { Jimenez-Jimenez et al. (2019); Nagy et al. } \\
\text { (2018); Richey et al. (2016) }\end{array}$ \\
\hline $\begin{array}{l}\text { Explore the Internet of Things applications that strengthen } \\
\text { supply chain agility }\end{array}$ & Gružauskas et al. (2018); Li and Wang (2017) \\
\hline $\begin{array}{l}\text { Develop new big data techniques and creative uses to } \\
\text { facilitate the forecasting and improve the sustainability of } \\
\text { the supply chain }\end{array}$ & $\begin{array}{l}\text { Fosso Wamba et al. (2017); Tan et al. (2015); } \\
\text { Wang et al. (2016) }\end{array}$ \\
\hline \multicolumn{2}{|c|}{ Red cluster: Big data, personalisation and co-creation strategies } \\
\hline $\begin{array}{l}\text { Investigate the consequences deriving from the } \\
\text { fragmentation of marketing activities on the collaboration } \\
\text { and division of responsibilities between chief data officer } \\
\text { and chief marketing officer on corporate competitiveness }\end{array}$ & Quinn et al. (2016); Sleep and Hulland (2018) \\
\hline $\begin{array}{l}\text { Examine the drawbacks of using UGBD in the } \\
\text { implementation of 'user-centred' innovative strategies }\end{array}$ & Arthur and Owen (2019); Zhou et al. (2018) \\
\hline $\begin{array}{l}\text { Explore big data's impact on the formulation and } \\
\text { evaluation of co-creation engagement strategies }\end{array}$ & $\begin{array}{c}\text { Kunz et al. (2017); Trabucchi et al. (2018); Xie } \\
\text { et al. (2016) }\end{array}$ \\
\hline $\begin{array}{l}\text { Analyse the impact of data-driven open innovation } \\
\text { strategies on firm value capture mechanisms }\end{array}$ & $\begin{array}{c}\text { Cappa et al. (2019); Lepak et al. (2007); } \\
\text { Trabucchi et al. (2017) }\end{array}$ \\
\hline
\end{tabular}




\begin{tabular}{|c|c|}
\hline $\begin{array}{l}\text { Investigate the approaches, alternatives and impacts of big } \\
\text { data experimenting activities for business model } \\
\text { innovation }\end{array}$ & $\begin{array}{l}\text { Cheah and Wang (2017); Sorescu (2017); } \\
\text { Trabucchi and Buganza (2019a) }\end{array}$ \\
\hline \multicolumn{2}{|c|}{ Blue cluster: Big data, strategic planning and strategic value creation pathways } \\
\hline $\begin{array}{l}\text { Deepen the impact of big data analytics on corporate } \\
\text { governance processes and management's ways of thinking } \\
\text { for strategic planning purposes }\end{array}$ & $\begin{array}{l}\text { Mazzei and Noble (2017); Merendino et al. } \\
\text { (2018) }\end{array}$ \\
\hline $\begin{array}{l}\text { Conduct empirical research analysing the impact of big } \\
\text { data on strategic orientations }\end{array}$ & Gnizy (2019); Zeng and Khan (2019) \\
\hline $\begin{array}{l}\text { Investigate risks, limits and drawbacks of using big data in } \\
\text { strategy formulation }\end{array}$ & $\begin{array}{l}\text { Constantiou and Kallinikos (2015); Roden et al. } \\
\text { (2017) }\end{array}$ \\
\hline $\begin{array}{l}\text { Develop new models capable of opening the black box of } \\
\text { value creation paths starting from big data analytics } \\
\text { capabilities }\end{array}$ & $\begin{array}{l}\text { Mamonov and Triantoro (2018); Wang et al. } \\
\text { (2018) }\end{array}$ \\
\hline \multicolumn{2}{|c|}{ Green cluster: Big data and knowledge management } \\
\hline $\begin{array}{l}\text { Deepen the interrelationships between knowledge } \\
\text { management processes and big data value chain phases }\end{array}$ & $\begin{array}{c}\text { Harlow (2018); Landaeta Olivo et al. (2016); Le } \\
\text { Dihn et al. (2018); Pauleen and Wang (2017); } \\
\text { Sumbal et al. (2017) }\end{array}$ \\
\hline $\begin{array}{l}\text { Examine the synergies and limitations of big data analytics } \\
\text { compared to other decision-making methods and tools }\end{array}$ & Aversa et al. (2018); Xu et al. (2016) \\
\hline $\begin{array}{l}\text { Explore enablers (in terms of tools and organisational } \\
\text { factors) capable of strengthening collaboration and } \\
\text { knowledge sharing inside and outside the company }\end{array}$ & Moore (2017); Romanelli (2018) \\
\hline Seek solutions to the openness paradox & $\begin{array}{l}\text { Del Vecchio, Di Minin, et al. (2018); Sumbal et } \\
\text { al. (2019) }\end{array}$ \\
\hline
\end{tabular}

Table 3: Big Data-Strategy future research avenues

Below we provide, as an example, a brief description of some of these future research avenues, starting with those concerning the green cluster. A first future research avenue could deepen the issue of BD impact on the structure and functioning of KM systems and, consequently, on business processes. This firstly requires a deeper examination of the influence of BDA on information systems and technological platforms in order to investigate, for example, how much BDA adoption affects the company market sensing capacity (Richey et al., 2016) and how the tensions arising from the incorporation of external, mainly explicit, 'big knowledge' into organisational contextual knowledge (whose nature is mainly tacit) can be managed and limited (Pauleen and Wang, 2017; Sumbal et al., 2017). Secondly, the impact of BDA on Business Process Management practices should be explored in order to identify the organisational structure configurations that are capable of optimising the coordination and interconnection between business processes and a profitable use of the insights extracted from BD through adequate DSS (Brinch, 2018). In addition, we invite future contributors to delve deeper and examine how KM systems can better leverage the potentiality of incorporating information deriving from disparate BD sources (e.g. enterprises, customers, competitors, partners and public data) in order to enhance existing value generation mechanisms or create new ones (Le Dinh et al., 2018).

The second future research direction concerns the knowledge sharing and collaboration strategies that could be enabled by BD. In particular, we consider it interesting to identify the factors encouraging different companies and individuals to share more or less confidential information (Nagy et al., 2018), as well as to analyse the variables that positively or negatively influence the results of collaboration with strategic partners, such as the nature of widespread corporate culture (Moore, 2017) and the structure of existing power relationships (Richey et al., 2016). With reference to this last point, it could be also interesting to investigate, for example, how the design of virtual collaborative environments (Romanelli, 2018) and the adoption of appropriate customer engagement approaches (Kunz et al., 2017) impact on the effectiveness of co-creation strategies based on knowledge sharing with businesses customers and 
consumers. Besides, while the existing literature highlights the relevance of BD for the creation of value within the context of UDI strategies, it does not delve into the mechanisms through which firms can capture that value (Lepak et al., 2007). Further studies could therefore analyse the impact of data-driven OI strategies on firms' future profits (Cappa et al., 2019) as well as aim to develop new business models capable of directly linking BD to value capture (Trabucchi et al., 2017). Finally, new empirical studies are needed to investigate the contribution of BDAC to incremental and radical innovation processes and see whether and to what extent this contribution is mediated by SC collaboration capabilities (JimenezJimenez et al., 2019).

A further area of attention concerns the BDA impact, on the one hand, on corporate governance practices and management strategic culture and, on the other hand, on the division of managerial responsibilities. With reference to the first aspect, the challenges posed by BDA use require further investigations aimed at identifying the cognitive and dynamic capabilities that managers must possess to face these challenges successfully (Merendino et al., 2018), as well as the requirements and methods for the adoption of the 'data as a strategy' paradigm (Mazzei and Noble, 2017). Secondly, it is important to investigate the consequences of data proliferation and BDA adoption on the articulation of managerial responsibilities within the organisation. This can be done, for example, by investigating the most effective criteria to adopt for a successful collaborative relationship between chief data officers and chief marketing officers (Quinn et al., 2016) and by identifying innovative organisational learning models that allow to obtain an adequate degree of accountability concerning the strategy implementation process at each level of the company (Landaeta Olivo et al., 2016).

Lastly, a promising future research avenue concerns the risks, limits and drawbacks associated with the use of BDA to support strategic decisions, through which companies can convert BD into value. In the context of value co-creation strategies, further studies are needed to investigate new ways to formulate effective OI strategies considering both consumer privacy and company's intellectual property defence (Del Vecchio, Di Minin, et al., 2018). For instance, it could be interesting to investigate causes and effects of uncontrolled external BD and knowledge sharing and which variables and instruments could help to limit strategic knowledge leakage that would result (Sumbal et al., 2019). With regard to UCI strategies, it may be appropriate to investigate the implications related to the phenomenon of 'overresponding', i.e. the company tendency to 'excessively' respond to customer requests through continuous product or service innovations (Zhou et al., 2018). Finally, future researches should explore remedies and alternatives to an excessively 'mechanical' BDA application, which can sometimes return an overly simplified image of reality, thus limiting a conscious strategic planning implementation (Constantiou and Kallinikos, 2015).

\section{Conclusions}

This study proposes a mapping and a systematisation of the big data-business strategy research field through a bibliometric analysis and a systematic literature review. Four thematic clusters have been discovered. The first three clusters concern the following topics: big data and supply chain strategy; big data, personalisation and co-creation strategies; big data, strategic planning and strategic value creation pathways. The last cluster, which deals with the relationship between big data and knowledge management, represents, by position and content, a 'bridge' that brings together the three other clusters. Based on the authors' knowledge, this is the first study to systematise and discuss the literature concerning the relationship between these two fields.

The bibliometric analysis and literature review presented in Section 4 allowed us to propose a tentative research agenda with several future research avenues.

This study has three main limitations. First, some steps of the selection process may have been biased by researchers' interpretations. In line with the best methodological practices (e.g. Tranfield et al., 2003), this concern was addressed by performing a multiple human subject reading process whose reliability 
was confirmed by a Krippendorf's Alpha coefficient $(\mathrm{K})$ value greater than 0.80 . Second, Scopus was used as reference database. This limitation was addressed by cross-checking the search string results on Web of Science and EBSCO Business Premier databases. Finally, the present study is mainly focused on profit firms. Therefore, future contributions could investigate the strategic implications of big data also for public and non-profit organisations (Akoka et al., 2017; Jin et al., 2015).

We believe this research will prove useful to both scholars and managers. For the former, it offers a complete picture of the managerial literature on big data and firm strategy and identifies some interesting research gaps on which to base possible future studies. For the latter, it discloses the benefits of big data analytics implementation within existing organisational knowledge management systems in terms of supply chain optimisation, marketing and innovation strategies personalisation and more informed strategizing.

\section{References}

Ahani, A., Nilashi, M., Ibrahim, O., Sanzogni, L. and Weaven, S. (2019), 'Market segmentation and travel choice prediction in Spa hotels through TripAdvisor's online reviews', International Journal of Hospitality Management, Vol. 80, pp. 52-77.

Akoka, J., Comyn-Wattiau, I. and Laoufi, N. (2017), 'Research on Big Data - A systematic mapping study', Computer Standards \& Interfaces, Vol. 54, pp. 105-115.

Akter, S., Fosso Wamba, S., Gunasekaran, A., Dubey, R. and Childe, S.J. (2016), 'How to improve firm performance using big data analytics capability and business strategy alignment?', International Journal of Production Economics, Vol. 182, pp. 113-131.

Arora, P. and Predmore, C.E. (2013), 'Social media as a strategic tool: Going beyond the obvious', Advanced Series in Management, Vol. 11, pp. 115-127.

Arthur, K.N.A. and Owen, R. (2019), 'A Micro-ethnographic Study of Big Data-Based Innovation in the Financial Services Sector: Governance, Ethics and Organisational Practices', Journal of Business Ethics, Vol. 160 No. 2, pp. 363-375.

Aversa, P., Cabantous, L. and Haefliger, S. (2018), 'When decision support systems fail: Insights for strategic information systems from Formula 1', Journal of Strategic Information Systems, Vol. 27 No. 3, pp. 221-236.

Bendle, N.T. and Wang, X.S. (2016), 'Uncovering the message from the mess of big data', Business Horizons, Vol. 59 No. 1, pp. 115-124.

Boyack, K.W. and Klavans, R. (2010), 'Co-citation analysis, bibliographic coupling, and direct citation: Which citation approach represents the research front most accurately?', Journal of the American Society for Information Science and Technology, Vol. 61 No. 12, pp. 2389-2404.

Bresciani, S., Ferraris, A. and Del Giudice, M. (2018), 'The management of organizational ambidexterity through alliances in a new context of analysis: Internet of Things (IoT) smart city projects', Technological Forecasting and Social Change, Vol. 136, pp. 331-338.

Brinch, M. (2018), 'Understanding the value of big data in supply chain management and its business processes: Towards a conceptual framework', International Journal of Operations and Production Management, Vol. 38 No. 7, pp. 1589-1614.

Buhalis, D. and Leung, R. (2018), 'Smart hospitality - Interconnectivity and interoperability towards an ecosystem', International Journal of Hospitality Management, Vol. 71, pp. 41-50.

Buhalis, D. and Sinarta, Y. (2019), 'Real-time co-creation and nowness service: lessons from tourism and hospitality', Journal of Travel and Tourism Marketing, Routledge, Vol. 36 No. 5, pp. 563582.

Cappa, F., Oriani, R., Pinelli, M. and De Massis, A. (2019), 'When does crowdsourcing benefit firm stock market performance?', Research Policy, Vol. 48 No. 9.

Cheah, S. and Wang, S. (2017), 'Big data-driven business model innovation by traditional industries in 
the Chinese economy', Journal of Chinese Economic and Foreign Trade Studies, Vol. 10 No. 3, pp. 229-251.

Chesbrough, H. and Bogers, M. (2014), 'Explicating open innovation: Clarifying an emerging paradigm for understanding innovation', in Chesbrough, H., Vanhaverbeke, W. and West, J. (Eds.), New Frontiers in Open Innovation, Oxford University Press, pp. 3-28.

Constantiou, I.D. and Kallinikos, J. (2015), 'New games, new rules: Big data and the changing context of strategy', Journal of Information Technology, Vol. 30 No. 1, pp. 44-57.

Côrte-Real, N., Oliveira, T. and Ruivo, P. (2017), 'Assessing business value of Big Data Analytics in European firms', Journal of Business Research, Elsevier Inc., Vol. 70, pp. 379-390.

Côrte-Real, N., Ruivo, P. and Oliveira, T. (2019), 'Leveraging internet of things and big data analytics initiatives in European and American firms: Is data quality a way to extract business value?', Information and Management, Vol. 57 No. 1, pp. 1-16.

Del Vecchio, P., Mele, G., Ndou, V. and Secundo, G. (2018), 'Creating value from Social Big Data: Implications for Smart Tourism Destinations', Information Processing and Management, Vol. 54 No. 5, pp. 847-860.

Del Vecchio, P., Di Minin, A., Petruzzelli, A.M., Panniello, U. and Pirri, S. (2018), 'Big data for open innovation in SMEs and large corporations: Trends, opportunities, and challenges', Creativity and Innovation Management, Vol. 27 No. 1, pp. 6-22.

El-Kassar, A.N. and Singh, S.K. (2019), 'Green innovation and organizational performance: The influence of big data and the moderating role of management commitment and HR practices', Technological Forecasting and Social Change, Vol. 144, pp. 483-498.

Elia, G., Polimeno, G., Solazzo, G. and Passiante, G. (2019), 'A multi-dimension framework for value creation through big data', Industrial Marketing Management, pp. 1-15.

Falagas, M.E., Pitsouni, E.I., Malietzis, G. and Pappas, G. (2008), 'Comparison of PubMed, Scopus, web of science, and Google scholar: strengths and weaknesses', The FASEB Journal, Vol. 22 No. 2, pp. 338-342.

Festa, G., Safraou, I., Cuomo, M.T. and Solima, L. (2018), 'Big data for big pharma: Harmonizing business process management to enhance ambidexterity', Business Process Management Journal, Vol. 24 No. 5, pp. 1110-1123.

Fosso Wamba, S., Dubey, R., Gunasekaran, A. and Akter, S. (2019), 'The performance effects of big data analytics and supply chain ambidexterity: The moderating effect of environmental dynamism', International Journal of Production Economics.

Fosso Wamba, S., Gunasekaran, A., Akter, S., Ren, S.J. fan, Dubey, R. and Childe, S.J. (2017), 'Big data analytics and firm performance: Effects of dynamic capabilities', Journal of Business Research, Vol. 70, pp. 356-365.

Gnizy, I. (2019), 'Big data and its strategic path to value in international firms', International Marketing Review, Vol. 36 No. 3, pp. 318-341.

Grégoire, D.A., Corbett, A.C. and McMullen, J.S. (2011), 'The Cognitive Perspective in Entrepreneurship: An Agenda for Future Research', Journal of Management Studies, Vol. 48 No. 6, pp. 1443-1477.

Grover, V., Chiang, R.H.L., Liang, T.P. and Zhang, D. (2018), 'Creating Strategic Business Value from Big Data Analytics: A Research Framework', Journal of Management Information Systems, Vol. 35 No. 2, pp. 388-423.

Gružauskas, V., Baskutis, S. and Navickas, V. (2018), 'Minimizing the trade-off between sustainability and cost effective performance by using autonomous vehicles', Journal of Cleaner Production, Vol. 184, pp. 709-717.

Gupta, M. and George, J.F. (2016), 'Toward the development of a big data analytics capability', Information and Management, Vol. 53 No. 8, pp. 1049-1064. 
Handfield, R., Jeong, S. and Choi, T. (2019), 'Emerging procurement technology: data analytics and cognitive analytics', International Journal of Physical Distribution and Logistics Management, Vol. 49 No. 10, pp. 972-1002.

Harlow, H.D. (2018), 'Developing a knowledge management strategy for data analytics and intellectual capital', Meditari Accountancy Research, Vol. 26 No. 3, pp. 400-419.

Intezari, A. and Gressel, S. (2017), 'Information and reformation in KM systems: big data and strategic decision-making', Journal of Knowledge Management, Vol. 21 No. 1, pp. 71-91.

Jimenez-Jimenez, D., Martínez-Costa, M. and Sanchez Rodriguez, C. (2019), 'The mediating role of supply chain collaboration on the relationship between information technology and innovation', Journal of Knowledge Management, Vol. 23 No. 3, pp. 548-567.

Jin, X., Wah, B.W., Cheng, X. and Wang, Y. (2015), 'Significance and Challenges of Big Data Research', Big Data Research, Vol. 2 No. 2, pp. 59-64.

Kaufmann, M. (2019), 'Big Data Management Canvas: A Reference Model for Value Creation from Data', Big Data and Cognitive Computing, Vol. 3 No. 1, pp. 1-18.

Khan, Z. and Vorley, T. (2017), 'Big data text analytics: an enabler of knowledge management', Journal of Knowledge Management, Vol. 21 No. 1, pp. 18-34.

Kumar, V., Anand, A. and Song, H. (2017), 'Future of Retailer Profitability: An Organizing Framework', Journal of Retailing, Vol. 93 No. 1, pp. 96-119.

Kunc, M. and O'Brien, F.A. (2019), 'The role of business analytics in supporting strategy processes: Opportunities and limitations', Journal of the Operational Research Society, Vol. 70 No. 6, pp. 974-985.

Kunz, W., Aksoy, L., Bart, Y., Heinonen, K., Kabadayi, S., Ordenes, F.V., Sigala, M., et al. (2017), 'Customer engagement in a Big Data world', Journal of Services Marketing, Vol. 31 No. 2, pp. 161-171.

Landaeta Olivo, J.F., García Guzmán, J., Colomo-Palacios, R. and Stantchev, V. (2016), 'IT innovation strategy: managing the implementation communication and its generated knowledge through the use of an ICT tool', Journal of Knowledge Management, Vol. 20 No. 3, pp. 512-533.

LaValle, S., Lesser, E., Shockley, R., Hopkins, M.S. and Kruschwitz, N. (2011), 'Big Data, Analytics and the Path From Insights to Value', MIT Sloan Management Review, Vol. 52 No. 2, pp. 21-32.

Le Dinh, T., Phan, T.-C., Bui, T. and Vu, M.C. (2018), 'Towards a Service-Oriented Architecture for Knowledge Management in Big Data Era', International Journal of Intelligent Information Technologies, Vol. 14 No. 4, pp. 24-38.

Lepak, D.P., Smith, K.G. and Taylor, M.S. (2007), 'Value creation and value capture: A multilevel perspective', Academy of Management Review, Vol. 32 No. 1, pp. 180-194.

Li, D. and Wang, X. (2017), 'Dynamic supply chain decisions based on networked sensor data: an application in the chilled food retail chain', International Journal of Production Research, Vol. 55 No. 17, pp. 5127-5141.

Lugmayr, A., Stockleben, B., Scheib, C. and Mailaparampil, M.A. (2017), 'Cognitive big data: survey and review on big data research and its implications. What is really "new" in big data?', Journal of Knowledge Management, Vol. 21 No. 1, pp. 197-212.

Mäkelä, M.A. (2007), 'Knowing Through Making: The Role of the Artefact in Practice-led Research', Knowledge and Policy, Vol. 20 No. 3, pp. 157-163.

Mamonov, S. and Triantoro, T.M. (2018), 'The strategic value of data resources in emergent industries', International Journal of Information Management, Vol. 39, pp. 146-155.

Manyika, J., Chui, M., Brown, B., Bughin, J., Dobbs, R., Roxburgh Charles and Byers, A.H. (2011), 'Big data: The next frontier for innovation, competition, and productivity', McKinsey Global Institute.

Mazzei, M.J. and Noble, D. (2017), 'Big data dreams: A framework for corporate strategy', Business 
Horizons, Vol. 60 No. 3, pp. 405-414.

Mcafee, A. and Brynjolfsson, E. (2012), 'Big Data: The Management Revolution', Harvard Business Review, Vol. 90 No. 10, pp. 60-68.

Merendino, A., Dibb, S., Meadows, M., Quinn, L., Wilson, D., Simkin, L. and Canhoto, A. (2018), 'Big data, big decisions: The impact of big data on board level decision-making', Journal of Business Research, Vol. 93, pp. 67-78.

Mikalef, P., Framnes, V., Danielsen, F., Krogstie, J. and Olsen, D.H. (2017), 'Big Data Analytics Capability: Antecedents and Business Value', PACIS 2017 Proceedings, Langkawi (Malaysia).

Mishra, D., Luo, Z., Jiang, S., Papadopoulos, T. and Dubey, R. (2017), 'A bibliographic study on big data: concepts, trends and challenges', Business Process Management Journal, Vol. 23 No. 3, pp. $555-573$.

Moore, J. (2017), 'Data visualization in support of executive decision making', Interdisciplinary Journal of Information, Knowledge, and Management, Vol. 12, pp. 125-138.

Nagy, J., Oláh, J., Erdei, E., Máté, D. and Popp, J. (2018), 'The role and impact of industry 4.0 and the internet of things on the business strategy of the value chain-the case of Hungary', Sustainability (Switzerland), Vol. 10 No. 10, p. 3491.

Navickas, V. and Gružauskas, V. (2016), 'Big Data Concept in the Food Supply Chain: Small Markets Case', Scientific Annals of Economics and Business, Vol. 63 No. 1, pp. 15-28.

Nguyen Dang Tuan, M., Nguyen Thanh, N. and Le Tuan, L. (2019), 'Applying a mindfulness-based reliability strategy to the Internet of Things in healthcare - A business model in the Vietnamese market', Technological Forecasting and Social Change, Vol. 140, pp. 54-68.

O'Connor, C. and Kelly, S. (2017), 'Facilitating knowledge management through filtered big data: SME competitiveness in an agri-food sector', Journal of Knowledge Management, Vol. 21 No. 1, pp. 156-179.

Osuszek, L., Stanek, S. and Twardowski, Z. (2016), 'Leverage big data analytics for dynamic informed decisions with advanced case management', Journal of Decision Systems, Vol. 25, pp. 436-449.

Patel, N. V. and Ghoneim, A. (2011), 'Managing emergent knowledge through deferred action design principles', Journal of Enterprise Information Management, Vol. 24 No. 5, pp. 424-439.

Pauleen, D.J. and Wang, W.Y.C. (2017), 'Does big data mean big knowledge? KM perspectives on big data and analytics', Journal of Knowledge Management, Vol. 21 No. 1, pp. 1-6.

Pérez López, S., Manuel Montes Peón, J. and José Vázquez Ordás, C. (2004), 'Managing knowledge: The link between culture and organizational learning', Journal of Knowledge Management, Vol. 8 No. 6, pp. 93-104.

Power, D.J. (2015), “'Big data” decision making use cases', International Conference on Decision Support System Technology, pp. 1-9.

Prescott, M.E. (2014), 'Big data and competitive advantage at Nielsen', Management Decision, Vol. 52 No. 3, pp. 573-601.

Qi, J., Zhang, Z., Jeon, S. and Zhou, Y. (2016), 'Mining customer requirements from online reviews: A product improvement perspective', Information and Management, Vol. 53 No. 8, pp. 951-963.

Quinn, L., Dibb, S., Simkin, L., Canhoto, A. and Analogbei, M. (2016), 'Troubled waters: the transformation of marketing in a digital world', European Journal of Marketing, Vol. 50 No. 12, pp. 2103-2133.

Richard, B. (2017), 'Hotel chains: survival strategies for a dynamic future', Journal of Tourism Futures, Vol. 3 No. 1, pp. 56-65.

Richey, R.G., Morgan, T.R., Lindsey-Hall, K. and Adams, F.G. (2016), ‘A global exploration of Big Data in the supply chain: Global exploration of Big Data', International Journal of Physical Distribution and Logistics Management, Vol. 46 No. 8, pp. 710-739.

Roden, S., Nucciarelli, A., Li, F. and Graham, G. (2017), 'Big data and the transformation of 
operations models: A framework and a new research agenda', Production Planning and Control, Vol. 28 No. 11-12, pp. 929-944.

Romanelli, M. (2018), 'Museums creating value and developing intellectual capital by technology:

From virtual environments to Big Data', Meditari Accountancy Research, Vol. 26 No. 3, pp. 483498.

Ross, J.W., Beath, C.M. and Quaadgras, A. (2013), 'You May Not Need Big Data After All', Harvard Business Review, Vol. 91 No. 12, pp. 90-98.

Roßmann, B., Canzaniello, A., von der Gracht, H. and Hartmann, E. (2018), 'The future and social impact of Big Data Analytics in Supply Chain Management: Results from a Delphi study', Technological Forecasting and Social Change, Vol. 130, pp. 135-149.

Santoro, G., Fiano, F., Bertoldi, B. and Ciampi, F. (2019), 'Big data for business management in the retail industry’, Management Decision, Vol. 57 No. 8, pp. 1980-1992.

Sleep, S. and Hulland, J. (2018), 'Is big data driving cooperation in the c-suite? The evolving relationship between the chief marketing officer and chief information officer', Journal of Strategic Marketing, Vol. 27 No. 8, pp. 668-678.

Sorescu, A. (2017), 'Data-Driven Business Model Innovation', Journal of Product Innovation Management, Vol. 34 No. 5, pp. 691-696.

Sumbal, M.S., Tsui, E., Irfan, I., Shujahat, M., Mosconi, E. and Ali, M. (2019), 'Value creation through big data application process management: the case of the oil and gas industry', Journal of Knowledge Management, Vol. 23 No. 8, pp. 1566-1585.

Sumbal, M.S., Tsui, E. and See-to, E.W.K. (2017), 'Interrelationship between big data and knowledge management: an exploratory study in the oil and gas sector', Journal of Knowledge Management, Vol. 21 No. 1, pp. 180-196.

Tabesh, P., Mousavidin, E. and Hasani, S. (2019), 'Implementing big data strategies: A managerial perspective', Business Horizons, Vol. 62 No. 3, pp. 347-358.

Tan, K.H., Zhan, Y., Ji, G., Ye, F. and Chang, C. (2015), 'Harvesting big data to enhance supply chain innovation capabilities: An analytic infrastructure based on deduction graph', International Journal of Production Economics, Vol. 165, pp. 223-233.

Taylor-West, P., Saker, J. and Champion, D. (2018), 'Market segmentation strategies for complex automotive products', Journal of Strategic Marketing.

Tian, X. (2017), 'Big data and knowledge management: a case of déjà vu or back to the future?', Journal of Knowledge Management, Vol. 21 No. 1, pp. 113-131.

Todeschini, R. and Baccini, A. (2016), Handbook of Bibliometric Indicators: Quantitative Tools for Studying and Evaluating Research, Wiley-VCH, Weinheim.

Trabucchi, D. and Buganza, T. (2019a), 'Data-driven innovation: switching the perspective on Big Data', European Journal of Innovation Management, Vol. 22 No. 1, pp. 23-40.

Trabucchi, D. and Buganza, T. (2019b), 'Fostering digital platform innovation: From two to multisided platforms', Creativity and Innovation Management, pp. 1-14.

Trabucchi, D., Buganza, T., Dell'Era, C. and Pellizzoni, E. (2018), 'Exploring the inbound and outbound strategies enabled by user generated big data: Evidence from leading smartphone applications', Creativity and Innovation Management, Vol. 27 No. 1, pp. 42-55.

Trabucchi, D., Buganza, T. and Pellizzoni, E. (2017), 'Give Away Your Digital Services: Leveraging Big Data to Capture Value', Research Technology Management, Vol. 60 No. 2, pp. 43-52.

Tranfield, D., Denyer, D. and Smart, P. (2003), 'Towards a Methodology for Developing EvidenceInformed Management Knowledge by Means of Systematic Review', British Journal of Management, Vol. 14 No. 3, pp. 207-222.

Troisi, O., D’Arco, M., Loia, F. and Maione, G. (2018), 'Big data management: The case of Mulino Bianco's engagement platform for value co-creation', International Journal of Engineering 
Business Management, Vol. 10 No. 4.

Van Eck, N.J. and Waltman, L. (2010), 'Software survey: VOSviewer, a computer program for bibliometric mapping', Scientometrics, Vol. 84 No. 2, pp. 523-538.

Wang, G., Gunasekaran, A., Ngai, E.W.T. and Papadopoulos, T. (2016), 'Big data analytics in logistics and supply chain management: Certain investigations for research and applications', International Journal of Production Economics, Vol. 176, pp. 98-110.

Wang, Y., Kung, L.A., Wang, W.Y.C. and Cegielski, C.G. (2018), 'An integrated big data analyticsenabled transformation model: Application to health care', Information and Management, Vol. 55 No. 1, pp. 64-79.

Xie, K., Wu, Y., Xiao, J. and Hu, Q. (2016), 'Value co-creation between firms and customers: The role of big data-based cooperative assets', Information and Management, Vol. 53 No. 8, pp. 10341048.

Xu, Z., Frankwick, G.L. and Ramirez, E. (2016), 'Effects of big data analytics and traditional marketing analytics on new product success: A knowledge fusion perspective', Journal of Business Research, Vol. 69 No. 5, pp. 1562-1566.

Zeng, J. and Khan, Z. (2019), 'Value creation through big data in emerging economies: The role of resource orchestration and entrepreneurial orientation', Management Decision, Vol. 57 No. 8, pp. $1818-1838$.

Zhang, Y., Ma, S., Yang, H., Lv, J. and Liu, Y. (2018), 'A big data driven analytical framework for energy-intensive manufacturing industries', Journal of Cleaner Production, Vol. 197, pp. 57-72.

Zhou, S., Qiao, Z., Du, Q., Wang, G.A., Fan, W. and Yan, X. (2018), 'Measuring Customer Agility from Online Reviews Using Big Data Text Analytics', Journal of Management Information Systems, Vol. 35 No. 2, pp. 510-539.

\section{Deposit licences}

Emerald allows authors to deposit their AAM under the Creative Commons Attribution Non-commercial International Licence 4.0 (CC BY-NC 4.0). To do this, the deposit must clearly state that the AAM is deposited under this licence and that any reuse is allowed in accordance with the terms outlined by the licence. To reuse the AAM for commercial purposes, permission should be sought by contacting permissions@emeraldinsight.com.

For the sake of clarity, commercial usage would be considered as, but not limited to:

o $\quad$ Copying or downloading AAMs for further distribution for a fee;

o Any use of the AAM in conjunction with advertising;

o Any use of the AAM by for promotional purposes by for-profit organisations;

o Any use that would confer monetary reward, commercial gain or commercial exploitation.

Emerald appreciates that some authors may not wish to use the CC BY-NC licence; in this case, you should deposit the AAM and include the copyright line of the published article. Should you have any questions about our licensing policies, please contact permissions@emeraldinsight.com. 